\title{
Et kontranivellerende tids-skrift
}

\section{Kierkegaards En litterair Anmeldelse}

Det er som bekendt ikke i egenskab af litteraturanmelder, at Kierkegaard har indskrevet sig i verdenslitteraturen. Egentlige litteraturanmeldelser fylder da heller ikke alverden i hans samlede produktion; han har skrevet to. Til gengæld er disse af et omfang og en indholdsmæssig og stilistisk kompleksitet - eller måske endda monstrøsitet - så de frem for at optræde i en avis eller et tidsskrift endte med at blive selvstændige udgivelser. Også som anmelder fulgte Kierkegaard kort sagt en vej, der var alt andet end slagen. Således var Kierkegaards første recension, anmeldelsen af H. C. Andersens roman Kun en Spillemand i Af en endnu Levendes Papirer, af en beskaffenhed, der fik Heiberg til at nægte at publicere den i sit tidsskrift Perseus. Anden gang, da Kierkegaard i En literair Anmeldelse anmelder Thomasine Gyllembourgs novelle af romanlængde To Tidsaldre og erfarer at han selv, hvad omfang angår, har skrevet en mindre roman, vælger han - klog af skade? - uden videre at publicere den som en selvstændig bog. ${ }^{1}$

At Kierkegaard heller ikke som anmelder evnede at realisere det almene, gør ikke hans livtag med genren mindre interessante. Det er slående, i hvor ringe grad hans anmeldelser konformerer med historiens dom. Andersen, som Kierkegaard hudfletter i Af en endnu Levendes Papirer er indgået i verdenslitteraturen i mindst samme grad som Kierkegaard, mens Thomasine Gyllembourg, der skamroses i En Literair Anneldelse (herefter Anmeldelsen), i dag næppe læses af andre end professionelle litterater. Dog må det med det samme tilføjes, at det er som romanforfatter, at Andersen bortdømmes, hvilket historien har givet Kierkegaard et vist medhold i. På den anden side er To Tidsaldre fortalt på så tilpas kluntet en måde, at det

1. Som man kan læse i Kierkegaards forord: „Denne anmeldelse var, førend den paabegyndtes, bestemt for nordisk Literaturtidende. Dens Uforholdsmæssighed i Forhold til hiint Blads ringe Omfang, da endog dets halve Deel omfatter svensk og norsk Literatur, blev mig snart indlysende, item min Uduelighed til at skrive i Blade."Citeret efter bd.14 af Samlede Varker 1-20, København 1962, p. 9. Citater herfra, og fra andre værker i samme udgave, vil i det følgende blive anført med bindnummer efterfulgt af sidetal i parentes. 
virker frapperende, at Kierkegaard kan rose værket i så høje toner, som han gør. Men man kan under alle omstændigheder ikke beskylde Kierkegaard for at være inkonsekvent; allerede i Af en endnu Levendes Papirer fremhæves Gyllembourg, repræsenteret ved pseudonymet (eller »anonymet«) »Forfatteren af en Hverdags-Historie«, som en forfatter, der ikke lider af Andersens skavanker. Så meget desto mere nødvendigt er det at spørge, om Kierkegaard er redelig i sin egen husholdning, om han aflægger oprigtigt regnskab for sin opfattelse af de anmeldte værkers æstetiske kvaliteter, eller om han i det skjulte gør et helt andet regnskab op. Eftersom Heiberg er det ikke synderligt skjulte omdrejningspunkt for Kierkegaards anmeldervirksomhed, er det forholdet til ham, der må danne udgangspunkt for en undersøgelse heraf.

\section{Kierkegaard kontra Heiberg}

Som omtalt nægtede Heiberg at trykke Af en endnu Levendes Papirer. Motivationen herfor var, at han fandt den unge Kierkegaards stil ukaperlig, hvilket utvivlsomt har været sårende for sidstnævnte. At Heiberg reagerede negativt er imidlertid ikke vanskeligt at forstå. Som Peer E. Sørensen påpeger, ${ }^{2}$ er den digressive stil i Af en endnu Levendes Papirer udtryk for et markant brud på den heibergske æstetik, som Andersens romankunst umiddelbart set bedømmes ud fra i teksten. Allerede på dette tidlige tidspunkt fører Kierkegaard således dobbelt bogholderi. På den ene side ansøger han med teksten om optagelse i det litterært dannede selskab, der regeres af en næsten enevældig Heiberg, samtidig med at han underskyder en parodi på samme selskabs ærværdige principper. Hvor afklaret den unge Kierkegaard var om denne konflikt er vanskeligt at afgøre med bestemthed og måske også mindre væsentligt. Man kan nøjes med at konstatere, at samme historie gentager sig i Om Begrebet Ironi, hvor Kierkegaard afgjort er anderledes afklaret i forhold til, hvad han foretager sig.

Før publiceringen af Anmeldelsen i 1846 har Kierkegaard endnu et sammenstød med redaktøren og anmelderen Heiberg. Denne gang er det Gjentagelsen, det handler om. Heiberg leverer i 1843 en anmeldelse af værket i artiklen »Det astronomiske Aar» i skriftet Urania, en »Nytaarsgave«, som røber, at han ikke har fattet en meter af, hvad der er på færde i det - hvilket man nok skal passe på med at klandre ham alt for eftertrykkeligt for. Kierke-

2. Se artiklen »Den sindrige Edderkop« i When I'm sixtyfour, et festskrift til Hans-Jørgen Schanz, red. Tore Eriksen og Hans Jørgen Thomsen, Aarhus 1999. Artiklen supplerer glimrende den analyse af Af en endnu Levendes Papirer, som Jørgen Bonde Jensen leverer med "Af en endnu Levendes Papirer. Titlen på Søren Kierkegaards papir om H. C. Andersen« i hans samling af essays om Kierkegaard Jeg er kun en Digter, København 1996. 
gaard bliver så opbragt herover, at han begynder på et harmdirrende svar på anmeldelsen. Også denne tekst lider af et faretruende vokseværk, hvilket kunne være en af årsagerne til, at den forbliver i skrivebordsskuffen og først kommer for en dag med papirernes udgivelse. En anden kunne være at Kierkegaard ikke selv leverer en epokegørende læsning af sit værk.

Med til historien hører endvidere, at Kierkegaard i 1848 som en føljeton i »Fædrelandet« - her lykkedes det minsandten "at skrive i Blade $»^{3}-$ lod trykke Krisen og en Krise $i$ en Skuespillerindes Liv, som ligeledes er en art anmeldelse, nemlig en lovsang over Johanne Louise Heibergs præstation, da hun i 1847 for anden gang optrådte som Julie i Romeo og Julie. Kierkegaard var i langt tid i syv sind med hensyn til om han skulle publicere teksten eller ej. For publicering talte det faktum, at Kierkegaard, som der står i optegnelse A 175 fra bd. IX fra Papirerne: »(...) ønskede ogsaa at pirre lidt ved Heiberg. Jeg kan paa den Maade faae visse Ting sagt, som jeg ellers ikke faaer saaledes sagt, saa let, saa converserende.«Dixi!

Altså udvælger Kierkegaard de to kvinder, som må formodes at stå Heiberg nærmest, moderen Thomasine Gyllembourg ${ }^{4}$ og hustruen Johanne Louise, som mål for umådeholden ros. Hvorfor netop disse targets, hvis ikke for drilagtigt pirrende at etablere et sigende tomrum i forhold til den person, disse kvinder er fælles om i hverdagen at være familiært knyttet til? Dannes der kontrast på denne negative vis, er det i hvert fald sigende, at begge kvindelige kunstnere prises for den modenhed de i inderlighed har tilkæmpet sig. Om hverdagshistoriens forfatter skriver Kierkegaard, at »Muligheden af at kunne frembringe noget Saadant er snarere Lønnen, som Guden skjænkede Forfatteren, da han anden Gang modnet vandt i en LivsAnskuelse et Evigt« $(14,18)$, mens det om skuespillerinden ${ }^{5}$ hedder, at hun først nu, da hun igen optræder som Julie, »er ret egentligen Gjenstand for en væsenlig Kritik, nu da hun anden Gang og i anden Potens kommer til at forholde sig til den samme Idee eller nøiagtigere udtrykt, netop fordi det er anden Gang, kommer hun til rent ideelt at Forholde sig til Ideen« $(14,120)$.

I sin omtale af sig selv i Anmeldelsen er Kierkegaard lige så klædeligt beskeden, som hverdagshistoriens forfatter er i dennes forord til To Tidsaldre. ${ }^{6}$ Men eftersom Kierkegaard understreger, at han nu for anden gang

3. Det gjorde det også med den serie indlæg i samme publikation, der foregreb og akkompagnerede Kierkegaards eget blad Øieblikket. Men det er en helt anden historie. Den skriver Jørgen Bonde Jensen om i essayet "Søren Kierkegaards øjeblik« i samme samling, som blev nævnt i forrige note.

4. På det tidspunkt hvor To Tidsaldre udkom, var det en offentlig hemmelighed, at den der gemte sig bag pseudonymet »Forfatteren til en Hverdags-Historie« var Thomasine Gyllembourg.

5. Johanne Louise Heiberg nævnes ikke ved navn i skriftet. Anonymitet er, som vi videre skal se, på mange måder i og på spil i denne affære! 
optræder som litteraturanmelder, og lige som første gang skriver om hverdagshistoriens forfatter, åbner han op for den slutning hos læseren, at også anmelderen er modnet $\mathrm{i}$ åndens og idealitetens anden gang. I al beskedenhed luftes denne mulighed med disse ord:

»Det Første jeg har skrevet indeholdt blandt Andet nogle anmeldende Ord eller rettere en Udgydelse betræffende disse Noveller. Siden den Tid har jeg aldrig forsøgt mig som Anmelder. Efter 7 Aars Forløb er det da mit Ønske anden Gang, afsluttende, at gjøre Forsøget og atter med en Hverdags-Historie. Jeg har, hvad dog Sømmeligheden tillader i Forhold til en Anonym, en gjettende Formodning om Muligheden af, at den ærede ubekjendte Forfatter i sin Tid læste den lille Piece; dersom han nu da igjen vil gjøre mig den Ære at læse disse Linier: jeg haaber han skal finde mig uforandret eller om muligen forandret $i$ Gjentagelsen: lidt mere Klarhed i Fremstilling, lidt mere Lethed $i$ en flydende Stiil, lidt mere Langsomhed i Kjendskab til Opgaven, lidt mere Inderlighed i Skjønsomheden: altsaa forandret $i$ Gjentagelsen« (14, 25, mine kurs.).

Tales der her tillige til en beslægtet, men mindre anonym læser, Heiberg forstås, der gerne skulle annamme den større lethed i den flydende stil og finde en vis skribent forandret i Gjentagelsen (som hin læser måske burde have læst en ekstra gang)? Det lader sig ikke afgøre med nogen form for sikkerhed.

Under alle omstændigheder er det ikke sikkert, at den eksplicit hædrende omtale, der uden navns nævnelse bliver Heiberg til del i Anmeldelsen, udelukkende skal læses for pålydende:

»O, skjønt saaledes at være Forfatter [hverdagshistoriens, min anm.], skjønt at være den Navnkundige, der som Udgiver har lagt sit berømte Navn til [Heiberg, min anm.]; som Fortcellingerne ere det, saa er ogsaa dette Forhold en Forening $i$ Troskab« (14, 19, min kurs.).

6. Som sidstnævnte eksempelvis skriver i sit forord, „Forfatteren til Læseren«: »Men herved maa ikke tabes af Sigte, at Novellen har sine Indskrænkninger, at den forholder sig til Romanen, som Genrestykket til Historiemaleriet.«. Citeret efter udgaven i DSLs serie Danske Klassikere, København 1986, p. 75, alle følgende citater fra To Tidsaldre refererer hertil. Lad mig tillige give et eksempel på Kierkegaards analoge urbanitet: „Er det altid, efter min Overbeviisning, en Recensents Pligt at være en tjenende Aand [det kunne være interessant at høre H. C. Andersens reaktion på denne tilkendegivelse, min anm.], selv om han er i det sjeldnere Tilfælde at være Det langt overlegen, han anmelder: her er det ikke let for Nogen at falde i Fristelse, mig er det en Umulighed.« $(14,15)$ 
Det forholder sig ubestrideligt og ganske bogstaveligt således, som der gøres gældende i det citerede. Heiberg og fru Gyllembourg var forenede i den af det nære familieskabs medfølgende troskab. Men var den så trofast igen, samme troskab? Thomasine Gyllembourg lod sig som bekendt skille fra Johan Ludvigs far, Peter Andreas Heiberg, fordi hun forelskede sig stormende i og giftede sig med den svenske friherre Carl Frederik Gyllembourg. Som en konsekvens af denne efter datidens forhold bemærkelsesværdige handling levede hun en længere periode adskilt fra sønnen. Bag Kierkegaards underdanige hyldest gemmer der sig muligvis en spydig hentydning hertil. Igen er det ikke muligt at afgøre endegyldigt, om Kierkegaard er oprigtig eller ironisk. Men kan man efterspore en lignende spydighed andetsteds i teksten, er det selvfølgelig så meget mere sandsynligt, at han overalt skriver en dobbeltbundet diskurs. ${ }^{7}$

En sådan spydighed er åbenlys et andet sted i teksten, som jeg vil tillade mig at citere fyldigt fra:

"Som Modtagelsen var i Begyndelsen, saa var den den samme uforandrede, da Fortællingerne senere Aar efter Aar paa en saa smuk Maade udkom ved Juletid. Thi hvad der end kan indvendes imod, at gjøre en saa tilfældig Tid til Messe-Tid og fornemlig af en saa tilfældig Grund som den, at man behøver Præsenter, som var dansk Literatur slet ikke andet end Præsent-Literatur: Hverdags-Historien er aldrig paa den Maade kommen ved Juletid, dens egen Betydningsfuldhed maatte forhindre en fornærmelig Misforstaaelse, hvis ikke allerede dens tarvelige beskedne Udseende forhindrede enhver endog det første Øiekasts Misforstaaelse (...). Saaledes kom Hverdags-Historien ved Juletid. Det faldt Ingen ind, at det var en Bog man kjøbte, snarere var Penge-Udgiften som en Douceur, man giver Overbringeren af et kjært Budskab, Bogen var virkelig en Gave $(. ..) \ll(14,19-20)$.

Kierkegaard er således tidligt ude med en kritik af kommercialiseringen af julen: »at gjøre en saa tilfældig Tid til Messe-Tid«, sådan at den bliver en tid hvor man »behøver Præsenter«. Blandt de skyldige i en sådan kommercialisering, måske de værste af dem, er de udgivere, der kolporterer diverse lit-

7. Kierkegaard er i det hele taget ikke ubekendt med at adsplitte to, som er forenet i troskab. I Om Begrebet Ironi kan man for eksempel læse følgende tilkendegivelse: „Og saaledes nærme vi os nu det Problem, hvad tilhører i den platoniske Philosophi Socrates, og hvad tilhører Plato, et Spørgsmaal, vi ei kan afvise, hvor smerteligt det end er at adskille dem, som saa inderlig ere forenede." $(1,88)$ Men her er pointen naturligvis, at et sådant forehavende på forhånd er dømt til at mislykkes, så sandt som det er umuligt at afgøre, om det billede man får af Sokrates hos Platon er sandfærdigt eller ej. 
terære arbejder som jule- og nytårspræsenter. Iblandt dem kan tælles Heiberg, der, som tilfældet var med omtalte "Nytaarsgave», Urania, udgav langt flere stykker litteratur end hverdagshistorierne på denne måde - og kun hverdagshistorierne er ifølge Kierkegaard ubesmittede af en sådan lancering. ${ }^{8}$ Passagen er i det hele taget gennemsyret af ironi. Brugen af ordet »Præsent« associerer til præsens, altså til den »Nutid«, der både i To Tidsaldre og Anmeldelsen fremstilles i al sin indholdsløse hulhed. Som modpol har vi ordet "Gave«, der dermed logisk forlenes med et skær af tidløshed i positiv forstand. Heiberg er, i hans underforståede stræben for i egenskab af udgiver at forvandle den danske litteratur til en »Præsent-Literatur», placeret i den åndløse nutid, mens hverdagshistoriens forfatter, den glade, egentlige giver af gaven, diskret men aldeles ufrivilligt er lempet over på Kierkegaards polemisk utidssvarende parti. Hermed er en kile på skrømt forsøgt drevet ind mellem de i troskab forenede. Kierkegaard bemægtiger sig således den modsætning, To Tidsaldre er funderet i, dikotomien imellem åndsforladt nutid og lidenskabelig revolutionstid, og turnerer den på en måde, der diskret håner sønnen, udgiveren.

Hvor det efter alt at dømme kun var stilen, der gjorde oprør mod den heibergske æstetik i Af en endnu Levendes Papirer, er der altså i Anmeldelsen underskudt en konsekvent gennemført subtekst, der på en langt mere ondsindet måde søger at underminere dannelseskulturens øverste smagsdommers autoritet. Om dette mål helliger de anvendte midler, skal jeg lade være usagt. I stedet vil jeg påpege, at det gedulgte opgør med Heiberg også i Anmeldelsen dækker sig bag, hvad der ligner en eksplicit bekendelse til hans æstetik. De temaer, som ligefremt optager Kierkegaard: repræsentations-problematikken og offentlighedens forvandling til et anonymt publikum, kunne uden videre være hentet ud af Heibergs samtidskritiske afhandling "Folk og Publicum» fra 1842. ${ }^{9}$ I det hele taget danser Kierkegaard en underfundig pas de deux med denne tekst.

Det er allerede ironisk, at Heiberg heri efterlyser en karakter, som Kierkegaards version af nutiden i Anmeldelsen synes at råbe på, nemlig »et

8. Her vil det være på sin plads at citere, hvad Kierkegaard, med Constantin Constatius som pennefører, indledningsvist skriver i sit harmdirrende svar på Heibergs anmeldelse af Gjentagelsen: „Da jeg selv har udgivet en lille Bog, i hvilken Troen paa Gjentagelsen statueres, saa maatte jeg jo, ja saa maatte jeg jo være stjernegal, om jeg ikke med Glæde modtog et betydningsfuldt Beviis, naar dette tilbydes paa en for mig smigrende Maade. Thi skulde ikke endog en mindre Troende vindes for Troen paa Gjentagelsen ved at see, hvorledes hvad en obscur Person i en underordnet Sphære har sagt i <en> tarvelig ja næsten fattig paaklædt Bog, vandt ved at gjentages af den navnkundige Professor Heiberg, i en scerdeles elegant og nitid Nytaarsgave (...).«(citeret efter bd. IV af Søren Kierkegaards Papirer IXIII,2, København 1968, optegnelse B 110, p. 258, mine kurs. ).

9. Jeg refererer i det følgende til udgaven heraf i sjette bind af Heibergs Prosaiske Skrifter IXI, København 1861-62. 
Genie, som virkelig forstaaer sin Tidsalders Bevægelser, og med et rask Spring sætter sig ud over den hele Kjellingesnak og Vartougspassiar.» (p. 266). Samtiden er for Heiberg karakteriseret ved indholdsløs snaksomhed og der kræves derfor et geni - Heiberg selv? - som forstår at skære igennem ordskvalderen. Ifølge Heiberg er problemet med tiden nærmere bestemt, at folket er ophørt med at være en organisme og har forvandlet sig til en masse, hvilket vil sige en mængde individer, som ikke er væsentligt interesserede i, hvad de forholder sig til. En sådan masse består derfor af en mængde atomiserede individer, og en sådan benævnes »Publicum«. Begrebet publikum er således negativt ladet for Heiberg, ganske som tilfældet er for Kierkegaards vedkommende.

I Folk og Publicum«er det afgørende problem ved massen altså, at ingen af dens atomiserede individer er en del af et organisk hele; ingen enkeltindivider reprcesenterer noget som helst. At være en del af en organisme er for Heiberg ensbetydende med, at man på en legitim måde repræsenterer denne. Selv den revolutionære kan være en berettiget figur, hvis han repræsenterer et nødvendigt moment i en given historisk kontekst. På en anden side er det ifølge Heiberg i en revolutionær situation altid folkets tendens at forvandle sig til et publikum af ikke-repræsenterende individer. Publikum opstår i det hele taget ved en overgang fra »en organisk Repræsentation til en atomistisk, intet repræsenterende Mængde.« (p. 267) I Anmeldelsen er det ligeledes i den indolente nutid, der aldrig kan tage sig sammen til en afgørende handling, at folket reduceres til et publikum, en masse af individer. Imidlertid kan disse stadigvæk repræsentere - de kan faktisk ikke andet - til gengæld kan de ikke have en repræsentant:

„Publikum er et Corps, talrigere end alle Folk tilsammen, men dette Corps kan aldrig blive mønstret, ja det kan end ikke saa meget som have en eneste Repræsentant, fordi det selv er en Abstraktion« $(14,83) .^{10}$

For Kierkegaard er det, at de enkelte individer udelukkende repræsenterer altså blot tager sig ud - og som følge heraf ikke kan repræsenteres, et symp-

10. Kierkegaard er således tidligt ude med sin diagnose af den fuldstændig indholdsløse, men dog så frygtede magt, der udgår fra »den offentlige mening og »det tavse flertal «, hvilket følgende citat demonstrerer til fulde:»For at Nivelleringen egentligen skal komme istand, maa der først bringes et Phantom tilveie, dens Aand, en uhyre Abstraktion, et altomfattende Noget som er Intet, et Luftsyn - dette Phantom er Publikum. Kun i en lidenskabsløs, men reflekteret Tid kan dette Phantom udvikle sig ved Hjælp af Pressen, naar denne selv bliver en Abstraktion«(p.p.). Og lige så profetisk, diverse reality-programmer in mente, hedder det videre: »Thi Publikum er det Offentlige, der interesserer sig for det allermeest Private.«(p. 91) 
tom på en sygdom, han med et lån fra To Tidsaldre betegner som "Repræsentations-Syge«:

"(...) Personerne $i$ anden Deel traede langt tydeligere frem, hørlige i Replikkens Stikord, synlige i Skikkelsens Omrids, let gjenkendelige i Livet; medens Personerne $i$ forste Deel mere ere skjulte $i$ en universellere Lidenskabs Inderlighed (...). Forskjellen udtrykker egentligen Forholdet mellem Inderlighed og Reprosentations-Syge, for hvilken sidste netop Nutiden jo ofte sigtes« $(14,34)$.

Kierkegaard og Heiberg bruger således det samme ord, men mener noget forskelligt med det. Det repræsenterende individ er hos Heiberg en synekdoke, en del der står (inde) for en organisk helhed, mens samme individ hos Kierkegaard er et i luften frit svævende tegn, et simulakrum, der kun kan stå for (og derfor ikke stå inde for) sin fænomenale fremtræden. Det kan derfor ikke undre, at de er uenige om, hvilken art af krise samtiden befinder sig i, og hvad der kan gøres ved den. Ifølge Heiberg er krisen kun midlertidig og for så vidt et sundhedstegn:

„Idet man paa den ene Side bør indrømme, at Folkets Opløsning til et Publicum, Organismens til en Masse, eller - med nærmere Hensyn til Litteratur og Kunst - at Publicums egen Overgang fra en organisk Repræsentation til en atomistisk, Intet repræsenterende Mængde, er, som enhver Desorganisation, et Tilbageskridt: saa bør man igjen paa den anden Side indsee, at en saadan Gjæringstilstand er en nødvendig Følge af Tidsalderens retmæssige Emancipations-Idee, og vistnok Overgang til en ny og fuldkomnere Organisation« (p. 267).

Hvis historien ad sin dialektiske vej skrider fremad mod fuldkommengørelse, mod en realisering af en »Emancipations-Idee«, udgør den herskende forvirring således et nødvendigt, og derfor retfærdiggjort, negativt moment i denne udvikling. Men hvad er da geniets opgave, hvad kræves af dén, som med et rask spring sætter sig ud over kællingesnakken og passiaren? Geniet skal simpelthen gøre opmærksom på det uholdbare i den samtidige tilstand for så meget desto hurtigere at få sat kursen mod den kommende, mere fuldkomne organisation:

"Ligesaalidt som man derfor skal udgyde sig i elegiske Veeklager over en Tilstand, som er Grundet i Tingenes Natur, ligesaalidt skal man paa den anden Side benægte, at denne Tilstand, uagtet den kan være god i sin Relation til et Kommende, jo, i sig selv betragtet, er slet, og især skal 
man stræbe at tilegne sig og udbrede denne Erkjendelse, eftersom Dette er det kraftigste Middel til at forkorte Tilstanden (...)«(p. 267-68).

Kierkegaard efterlyser på sin side en karakter, der adskiller sig radikalt fra et geni af denne art, eftersom han kalder på en indirekte meddeler, måske endda en martyr, hvilket jeg vil tillade mig at vente med at komme ind på. For indeværende vil jeg blot konstatere, at Kierkegaard, på trods af hans brug af en tilsyneladende Heiberg-influeret terminologi, skriver en tekst, hvis termer og kategorier har et andet betydningsindhold end hos Heiberg, og hvis tendens i det hele taget går i en ganske anden retning end tilfældet er i »Folk og Publicum ${ }^{11}$

\section{Revolutionstiden kontra nutiden}

Det er imidlertid ikke kun denne tekst, som Kierkegaard for en første betragtning skriver i forlængelse af. Jeg har allerede strejfet, at der også er overlap imellem terminologien i To Tidsaldre og Anmeldelsen. Den karakter, der i hverdagsnovellen udbreder sig om og holder dom over nutiden er advokat Dalund, hvis vigtigste udtalelser desangående alle falder ved det samme middagsselskab. For en første betragtning overtager Kierkegaard denne røst således at Anmeldelsen på det nærmeste kan læses som Dalunds forlængede talerør. Jeg vil anføre et par eksempler. Dalund bemærker blandt andet, at:

"Naar jeg, som uophørlig skeer, møder disse Koner og Piger af den simpleste borgerlige Classe i deres af Pynt og Stads overlæssede Costume, der fordetmeste snarere viser end skjuler, at disse Damer ikke ere Damer, saa er jeg ikke langt fra ogsaa at helde til den Mening, at den megen Anledning til at vise sig, til at søge al sin Glæde udenfor det huus-

11. Der kan da også med udgangspunkt i »Folk og Publicum« opregnes en lang række markante forskelle på Heibergs og Kierkegaards respektive positioner. For Heiberg er det det enkelte individs fornemste pligt at indordne sig under den større organiske sammenhæng, det er indfældet i. Et individ tilhører adskillige interessefællesskaber, såsom en familie, en stand og en stat, og er i eminent forstand forpligtet herpå. Kierkegaards yndlingskategori, "hiin Enkelte«, i sin mest radikale udgave det religiøst ramte undtagelsesmenneske, er, set fra en sådan synsvinkel, en uting. Endvidere omtaler Heiberg både litteraturen og kirken som "opdragelsesinstitutter«, der som dannelsens forvaltere har både "Autoritet « og "Superioritet«. Kierkegaards religiøst motiverede problemer med spørgsmålet om myndighed er for en sådan betragtning irrelevante. Og når Heiberg med positiv ladning taler om »en politisk Menighed «(p. 272), er det ikke svært at forestille sig Kierkegaard rejse børster over en sådan kategorisammenblanding. 
lige Liv, nærer den gængse Reprcesentations-Lyst, der vistnok er latterlig og demoraliserende« (p.198, mine kurs.).

Denne opfattelse af, hvad der skal forstås ved begrebet om repræsentation, har jeg allerede nævnt at Kierkegaard deler. Således skriver han, som jeg har citeret ham for, at forskellen imellem revolutionstiden og nutiden i novellen angår "Forholdet imellem Inderlighed og Reprcesentations-Syge», samt at »(...) en lideskabsløs Tid eier intet Valuta; Alt bliver en Omsætning i Reprcesentativer." $(14,69)$ Om det demoraliserende ved nutiden anfører Kierkegaard: „Socialitetens forgudede positive Princip i vor Tid er netop det Fortærende, det Demoraliserende, der i en Reflexions Trældom gjør selv Dyderne til vitia splendida.« $(14,79)$ Som det fremgår, samles de kategorier, Dalund anvender for at indkredse nutiden op, og viderereflekteres i Anmeldelsen. Dette gælder også for begrebet lefleri, nutidens skødesynd per excellence. Herom bemærker Dalund:

"Men Kjærlighed, naar den virkelig fortjener dette Navn, er i sig selv noget Ædelt og Skjønt. Maa man end i dens Vildfarelser fordømme den, foragte den kan man dog ikke. Men Lefleriet kan man kun foragte. Kjærlighedens Fejl ere menneskelige, men Lefleriets kunne man kalde dæmoniske, thi de ere som Spøgeri, som Skygger, der i sig selv ere tomme og uden Sjæl.» (p. 200)

Unægtelig en formulering, der klinger mere kierkegaardsk end heibergsk. Førstnævnte har heller ikke besvær med at tage tråden op:

»Hverken den væsentlige Elsker eller den væsentlige Udsvævende forskylder Lefleriet, der gantes med Muligheden. Lefleriet er derfor en Indulgents i at turde tangere det Onde, og et Aflad fra at realisere det Gode.» $(14,93-94)$

Set i dette perspektiv virker Kierkegaards underdanighed over for forfatteren af hverdagshistorien troværdig. Anmelderen fremstår som en tjenende ånd, der gladelig tager imod de stikord, det anmeldte værk forsyner ham med. I realiteten gør han dog andet og mere end det. I novellen er nutidens Dalund i al væsentlighed en nostalgiker, der kan gøre sig sine betragtninger over nutidens indholdsløshed, fordi han stadig er plantet i fortiden, nærmere bestemt revolutionstiden, med begge ben. Anmelderen tager, som påvist, afsæt i disse betragtninger, men han er en alt andet end resigneret, nostalgisk personage. Mod slutningen af Anmeldelsen gennemfører han, for ret at få sat nutiden skakmat, en imponerende dialektisk analyse af den, som med 
garanti kunne fjerne enhver fast grund under Dalunds fødder. Kierkegaard sammenfatter sit dialektiske signalement af nutiden med disse flot svungne formuleringer, hvormed Anmeldelsen for alvor træder i karakter som tidsog strids-skrift:

„Hvad er det at snakke? Det er ophævelsen af den lidenskabelige Disjunktion mellem at tie og tale. Kun Den, der væsentligen kan tie, kan væsentligen tale, kun Den, der væsentligen kan tie, kan væsentligen handle. Tausheden er Inderligheden. Snakken anticiperer den væsentlige Talen, og Reflexionens Yttring svækker ved Forprang Handlingen« (14, 89).

"Hvad er Formløshed? Det er den ophævede lidenskabelige Distinktion mellem Form og Indhold, der derfor vel, til Forskjel fra Galskab og Dumhed, kan have Sandhed til Indhold, men det Sande, den indeholder, kan aldrig være væsentligt sandt« $(14,91)$.

"Hvad er Overfladiskhed, og denne Lyst: 'Repræsentations-Lysten'? Overfladiskhed er den ophævede lidenskabelige Distinktion mellem Skjulthed og Aabenbarelse (...). Og Repræsentations-Lysten er Reflexions-Indbildningens Selvforgabelse. Inderlighedens Skjulthed faaer ikke Tid til at sætte et Væsentligt af, der kan vorde en Aabenbarelse, men plumres længe før Tiden $(. .).(14,93)$.

"Hvad er Leflerie? Det er den ophævede lidenskabelige Distinktion mellem væsentligen at elske, og væsentligen at være udsvævende.«(s. p. )

"Hvad er det at raisonere? Det er den ophævede lidenskabelige Disjunktion mellem Subjektivitet og Objektivitet. Som abstrakt Tænkning er Raisonnementet ikke dialektisk dybt nok, som Mening og Overbeviisning er det uden Individualitets-Fuldblodighed« $(14,94)$.

Med det anaforisk gentagne indledende spørgsmål og den ligeledes repeterede »ophævede Distinktion« - eller »Disjunktion« - foranstalter disse formuleringer fordelt over nogle få sider et svimlende crescendo i teksten, en hvirvel, der nok kan matche refleksionens og nivelleringens ditto. Hvor man skulle forvente, at skarpe distinktioner, som de her gennemførte, ville befordre overblikket og klarheden, fremprovokerer de idelige gentagelser snarere en tranceagtig orienteringsløshed hos læseren; man føler sig som en snurretop i Kierkegaards dialektiske menageri. Frem for at danne sig et overblik over mekanismerne bag nivelleringen og dennes konsekvenser, får man lov 
til at føle den svimmelhed, som ophævelsen af ethvert modsætningsforhold i nutiden ultimativt må afstedkomme, på sin egen krop. Et stykke kierkegaardsk performancekunst, der ligger tæt op ad Begrebet Angest, hvor den toptunede dialektik hurtigt får læseren til at erfare angstens svimmelhed.

Nivelleringen er nemlig: »ikke en Enkelts Handling, men et ReflexionsSpil i en abstrakt Magts Haand«, $(14,79)$ den er »Abstraktionens Seier over Individerne.» $(14,78)$ Ingen, hverken enkeltpersoner eller nationaliteter, kan standse denne abstraktion, der som en passat fortærer alt. (cf. 14, 80) ${ }^{12}$ Læseren af Anmeldelsen finder sig mod slutningen netop overgivet til en sådan forslugen, abstrakt magt. Denne magt tømmer, som det fremgår, nutiden for enhver rest af substantiel betydning, den endnu måtte gøre krav på at besidde. Enhver distinktion, ethvert modsætningsforhold, selv det helt fundamentale mellem subjekt og objekt, ophæves. Dialektikken er negativ i bogstaveligste forstand, nærmest nedmejende; teksten svinger, hvad den selv omtaler som »Nivelleringens skarpe Lee« $(14,99) .{ }^{13}$

Hvad vi er vidne til, kunne man således kalde for en kontranivelleringens kunst; selv ikke det ringeste af nutidens hoveder vil vove at titte frem, efter at anmelderen har gennemført denne tour de force. Hvad meningen er med denne kontranivellering, skal jeg snarest komme ind på. Først vil jeg imidlertid lige se på, hvad der er blevet tilbage af hverdagsnovellen To Tidsaldre.

\section{Refleksionsforhold}

Kierkegaard har, som vi har erfaret, udviklet og gennemreflekteret de dialektiske forhold, der karakteriserer og bestemmer den nutid, hvis refleks i det huslige liv, hverdagsnovellen efter forfatterens udsagn vil fremstille. Og reelt set står hverdagshistorien, trods alle Kierkegaards forsikringer om det modsatte, tilbage som en yderst beskeden refleks af Kierkegaards dialektiske kunststykke. Kierkegaard mener muligvis i fuld alvor, at forfatterens fremvisning af nutidens refleks i det huslige liv bygger på en dialektisk refleksion

12. Nivelleringen er således en fætter til den »totale ironi« fra Om Begrebet Ironi: »Men denne Herre er ingen anden end den totale Ironi, der, naar alle Smaatræfninger ere udkæmpede, naar alle Høider ere sløifede, skuer ud over det totale Intet, bliver sig bevidst, at der Intet blev tilbage, eller rettere, at det, der blev tilbage, er Intet.« $(1,154)$

13. Forfatteren af hverdagshistorien er enig med Kierkegaard i, at den konsekvente nivellering er nutidens sag. Nok rullede der hoveder i revolutionstiden, men revolutionens idé var i To Tidsaldre ikke som udgangspunkt at udslette alle forskelle. Som Lusard, efterkommeren af en af den franske revolutions sønner, formulerer det i romanen:»(...) min Fader vilde - som man siger - vende sig i sin Grav, om han hørte,at den Frihed og Lighed, for hvilke han har givet Liv og Blod, skulde bestaae i at nægte Fortjenesten dens Krands og Arbeideren hans Løn, i at afhugge de Hoveder, som hæve sig over Mængden, for at Alle kunne blive lige Høie« (p. 215). 
over forholdet imellem nutid og revolutionstid, der i omfang og konsekvens kan matche hans egen, men det vil det næppe nogensinde lykkes ham at overbevise sin læser om. Når Kierkegaard er færdig med at svinge leen over nutiden, står To Tidsaldre ikke tilbage som stort mere end den anledning, Kierkegaard ofte fremhæver, at han er afhængig af. Anmeldelsen er kort sagt såre langt fra at være en refleks af To Tidsaldre, snarere forvandler Kierkegaards tekst sin anledning til en refleks af sig selv.

I overensstemmelse med en sådan læsning er Kierkegaard faktisk allerede fra anmeldelsens begyndelse i færd med at skære Gyllembourgs tekst til efter sit eget værks parametre. Hvorledes han benytter sig af sine egne begreber om gentagelsen, herunder åndens anden gang, har jeg allerede gjort opmærksom på. Dertil deklineres hverdagshistoriens forfatters æstetisk-etiske position efter stadielærens kategorier:

"Saaledes er denne Forfatter bestandig Virkeligheden lige nær og lige fjern, han er den i Opfattelsen nærmere end en Digter og i den forklarede Gjengivelse mindre fjern end en Digter; thi Forfatterens Livs-Anskuelse ligger i Confiniet mellem det Esthetiske hen til det Religieuse« $(14,17)$.

Både forfatter og værk fremstår derved som reflekser af et andet værk, nemlig Kierkegaards. Men dette forhold kan næppe være begrundet i nogen form for polemik mod Heiberg. Så hvorfor går anmelderen Kierkegaard egentlig til værks, som han gør i Anmeldelsen?

\section{Peripetien}

Det gør han, skulle jeg mene, for gradvist at sætte sin helt egen dagsorden og ubemærket træde ud af den tjenende anmelders rolle. Og det vil nærmere bestemt sige, at han midt i nivelleringens udviskning af forskelle vil gøre det muligt at spille sin egen afgørende kontranivellerende trumf ud.

Hvis nivelleringen drives vidt nok, og det vil sige til det punkt, hvor enhver differens er udslettet, indtræffer der nemlig et dialektisk vendepunkt, en veritabel peripeti, som tillader, at der for alvor kan sættes en forskel af kierkegaardsk tilsnit. For når alle modsætninger har annulleret hinanden i nivelleringens negative kontrapunkt, når alt væsentligt er ophørt med at have betydning, så er det enkelte individ endegyldigt atomiseret. I en sådan situation forefindes kun »hiin Enkelte« en masse. Og så er det, at Gud ret kan få fat på hvert enkelt individ - hvis det enkelte individ selv vil det; 
»Nivelleringens Abstraktion, denne Menneske-Slægtens Selvantændelse, foranlediget ved den Friktion, der opstaar, naar den individuelle Inderligheds Udsondring i Religieusitet udebliver, vil blive staaende som man siger det om en Passat, som fortærer Alt, men ved hvilken Individerne, hver især, igjen kan opdrages religieust, i høieste Forstand kan hjælpes til, i Nivelleringens examen rigorosum at vinde Religieusitetens Væsentlighed i sig selv. For den Yngre, der, hvor fast han end for sit Vedkommende hænger ved hvad han beundrer som Udmærket, fra Begyndelsen fatter, at Nivelleringen er hvad den selviske Enkelte og den selviske Slægt tænkte til det Onde, men ogsaa hvad for den Enkelte, hver især, hvis han saa vil det i Oprigtighed med Gud, kan blive Udgangspunktet for det høieste Liv - for ham vil det være i Sandhed dannende at leve i Nivelleringens Tid« (14, 80-81).

»Det høieste Liv« er, i Kierkegaards kontekst, selvsagt det kristne liv, således som han forstår denne form for eksistens.

Men lad os for et kort øjeblik kaste blikket tilbage mod „Folk og Publicum«. For Heiberg var publikums tid, nivelleringens tid, kun en overgang, mens denne uhyrlige abstraktion ifølge Kierkegaard "vil blive staaende« og fortære alt. Dette er imidlertid ikke ubetinget en katastrofe, det kan tværtom, for den ret disponerede, vise sig at være en velsignelse. Ganske vist vil der ikke blive dannet en "ny Organisation« i Heibergs forstand, men den enkelte får, $i$ kraft af sin anonymisering og atomisering, en enestående mulighed for at blive religiøst dannet - eller opbygget. Når vi alle er blevet lige for nivelleringen er der mulighed for, at vi hver især indser, hvad det betyder, at vi ubetinget er lige for Gud. ${ }^{14}$ Nivelleringens ligegyldighed bliver paradoksalt en motor for det guddommelige "Lige for Lige«, der i det hele taget er et af Kierkegaards grundprincipper:

"Nivelleringens Abstraktion derimod er et Princip, ligesom Østens skarpe Vind, der ikke indlader sig med det enkelte Individ i noget intimere Forhold, men kun i Abstraktions-Forholdet, der er ligeligt for Alle. Ingen Helt lider da for Andre og hjælper Andre, Nivelleringen bliver selv den skarpe Tugtemester, der tager sig af Opdragelsen. Og Den, der lærer Maximum af Opdragelsen og bliver Maximum, han bliver ikke den Udmærkede Helt, den Fremragende, dette forhindrer Nivelleringen, der er consequent indtil sit Yderste, og han forhindrer det selv, fordi han har

14. Som det bemærkes i Anmelselsen: „(...) saaledes er det evige Liv ogsaa en Art Nivellering, og dog er det ikke saa, fordi Divisor er det: at være et i religieus Forstand væsentligt Menneske.« $(14,88)$ 
fattet Nivelleringens Betydning, nei han bliver kun et væsentligt Menneske i den fyldige Ligeligheds Forstand« $(14,81)$.

I den reflekterede nutid forvandles selv refleksionens snare således til vehikel for Kierkegaards berømte spring: "Reflexionen er en Slynge, hvori men fanges, men ved Religieusitetens begeistrede Spring bliver Forholdet et Andet, saa bliver den Slyngen, som kaster En i det Eviges Favn.» $(14,82)$ At der kan øjnes en sådan peripeti, et sådant vendepunkt, virker næsten for godt til at være sandt. Men Kierkegaard er ikke en større jubeloptimist, end han fremhæver, at det, der skitseres, kun er en mulighed, og at man i det hele taget ikke kan sejle rundt i nivelleringens, anonymitetens, abstraktionens og refleksionens farvande uden at være i den yderste livsfare:

"Og dette vil være det Modernes absolute Forskjel fra Oldtiden: at det Totale ikke er Concretionen, der understøtter, der danner den Enkelte, uden dog at udvikle ham absolut, men er en Abstraktion, der i sin abstrakte Ligelighed frastødende hjælper ham til at dannes absolut hvis han ikke omkommer. Det Trøstesløse i Oldtiden var, at den Udmærkede var, hvad de Andre ikke kunde være, det Begeistrende vil blive, at Den, der religieust vandt sig selv, kun er hvad Alle kunne vore" $(14,85)$.

Når man betænker hvilke odds man er oppe imod, når man vil realisere denne mulighed, er udsigterne altså dystre nok. Specielt når nu der i anonymitetens og nivelleringens tid ingen udmærkede helte er tilbage, der sætter alt ind på at hjælpe andre, og dermed næppe heller er nogen kærlig instans, der hjælper sin næste til at elske Gud. Helt så galt behøver det nu ikke at stå til. Der er godt nok ikke noget geni, der skærer igennem, afslører blændværket, og anviser den rette vej mod en ny og bedre organisation, men der kunne måske tænkes at være en eller flere stille eksistenser, der kan yde en form for hjælp. Ja, minsandten!

Der eksisterer faktisk nogle »Ukjendelige«, som udgør et art hemmeligt selskab, hvis medlemmer i det skjulte forsøger at hjælpe hver enkelt til at indlede et sandfærdigt forhold til Gud. Disse mystiske hjælpere introduceres således:

„Denne Formation er lige den dialektiske Modsætning til Propheter og Dommere; og som disses Fare var, ikke at blive respekteret i Forhold til deres respektive Myndighed, saa er de Ukjendeliges Fare, at blive kjendte, at blive forlokkede til at faae Anseelse og Betydning som Auctoritet, hvorved de vilde standse den høieste Udvikling. De ere nemlig 
ukjendelige, eller ligesom geheime Agenter ikke ifølge en privat Instrux fra Guddommen, thi dette er jo netop Propheternes, Dommernes Forhold, men de ere ukjendelige (uden Myndighed) i Følge af selv at have fattet det Almene i Ligeligheden for Gud, og i Følge af at de hvert Øieblik fatte dette i Ansvaret, hvilket forhindrer dem fra i Distraction at forskylde Form-Realisationens Inconsequents i Forhold til Anskuelsens Consequents. Denne Formation er den dialektiske Modsætning til den organiserende, ${ }^{15}$ der gjør Generationen, præformeret i de Udmærkede, til Understøttende for Individerne, da den nu som en Abstraktion, understøttet negativt af de Ukjendelige, vender sig polemisk mod Individerne - for at frelse Hver især religieust« (14, 97-98).

Hvor mange medlemmer mon denne nutidige formation af ukendelige kender de i øvrigt hinanden? - tæller? Hvor mange mon der sætter en dyd i at være uden myndighed og dertil, vel vidende at det vil koste dem hån og spot, vender sig polemisk mod individerne - for at frelse hver især religiøst? Er man tilstrækkelig fantasiforladt, er det overmåde vanskeligt at komme i tanke om mere end én mulig kandidat til sligt medlemskab - som uden tvivl er i godt selskab!

Vedkommende fortsætter imidlertid med kryptisk at beskrive den aktivitet, der i det skjulte udføres af de såkaldte "geheime Agenter«:

"Og dog skulle de Ukjendelige (i Forhold til deres respektive Grad) have dobbelt Arbeide i Sammenligning med de Udmærkede (af samme Grad) i en ældre Formation; thi de Ukjendelige maae bestandig arbeide - og tillige arbeide for at skjule det« $(14,99)$.

Agenterne, »de Ukjendelige«, lyder mere og mere som indirekte meddelere!

Kierkegaards ideale indirekte meddeler er nemlig en skjult ditto, altså ukendelig. Han lader sig frivilligt nivellere, han nivellerer faktisk sig selv, for at det menneske, han hjælper, ikke skal være sig bevidst at være blevet hjulpet. ${ }^{16}$ Derved ville den hjulpne nemlig risikere at komme til at stå i et forhold til hjælperen frem for i et forhold til Gud. Jeg vil derfor tillade mig at gøre kort proces og sætte lighedstegn imellem enhver af disse ukendelige og Kierkegaards indirekte meddeler.

15. Det frelsende moment, der anes konturerne af, er ingenlunde en »ny Organisation«, men, siges det ligeud, det stik modsatte af organisation, ergo desorganisation.

16. Se herom for eksempel talen »Kjerlighed søger ikke sit Eget«, specielt p. 261-67, i Kjerlighedens Gjerninger. 
Det er, set i lyset heraf, interessant, at anmelderen på et tidligere tidspunkt i Anmeldelsen gennemfører en delvis nivellering af sin egen position og tilskriver sig selv en form for ukendelighed:

"Vil Nogen sige, at hvad jeg her har fremsat, veed Enhver og kan Enhver sige, da er dette mit Svar: saa meget desto bedre, jeg ønsker ingen Fremragenhed, jeg har Intet mod, at Enhver veed det, med mindre det, at Enhver veed det og Enhver kan kan sige det, skulde betyde, at det skal fratages mig og deponeres i det negative Fællesskab. Faaer jeg blot Lov at beholde det, saa taber det for mig ikke i Værd derved, at Enhver veed $\operatorname{det} \ll(14,82)$.

Anmelderen insisterer her på sit eget inderlige forhold til, hvad han meddeler. Dette forhold må ikke fratages ham, hvilket selvfølgelig er ensbetydende med, at han kun lader sig nivellere til en vis og ganske bestemt grad. Men udadtil har han intet imod at være skjult på den måde, at hans udsagn går op i den anonymitet, der består i, at enhver ved og siger det samme, som han.

\section{Martyren kontra nutiden}

Det er imidlertid en ganske anden og anderledes selv-udslettende figur end den indirekte meddeler, der træder i karakter i Anmeldelsens afsluttende klimaks. Den karakter, der gestalter sig, overtager pludselig depechen fra de »Ukjendelige«. Pluralis bliver med ét til singularis: »den Ukjendelige«:

»Nivelleringens Tjenere ere kjendte af de Ukjendelige, men Magt eller Myndighed mod dem tør de Ukjendelige ikke bruge, thi da gaaer Udviklingen tilbage, fordi det i samme Øieblik vilde være aabenbart for en Trediemand, at den Ukjendelige var en Auctoritet, og saa var jo denne Trediemand forhindret i det Høieste. Kun ved en lidende Handling vil den Ukjendelige turde fremhjælpe Nivelleringen, og ved den samme lidende Handling dømme Redskabet. Han tør ikke overvinde Nivelleringen ligefrem, dette vilde være hans Afskeed, da det var at handle i Retning af Auctoritet, men han vil overvinde den lidende, og derved atter udtrykke Loven for sin Existents, som ikke er at herske, styre, lede, men lidende at tjene, at hjælpe indirecte. De, der ikke have gjort Springet, ville forstaae den Ukjendeliges lidende Handling som hans Nederlag, og de, der have gjort Springet, ville have en Forestilling om, at det var hans Seier, men de ville ingen Vished have, thi Visheden kunde de kun faae 
ved ham, og giver han et eneste Menneske den ligefrem: saa betyder det hans Afskeed, fordi han blev Guddommen utro og vilde spille Auctoritet, fordi han ikke lystrende Guddommen lærte at elske Menneskene uendeligt ved at tvinge sig selv, ikke svigefuldt ved herskende at tvinge dem, selv om de bade derom.« $(14,99)$

Denne ukendte figur er i sin yderste konsekvens ingen anden end Kierkegaards idé om den moderne martyr, der ved sit lidende offer tvinger samtiden til at blive opmærksom. Lykkes det ham at blive ombragt, vil der være en mulighed for, at dette uhyrlige faktum sætter en stopklods for nivelleringen. Den moderne martyrs problem er imidlertid, ifølge Kierkegaard, at det er svært at indgyde en lidenskabsløs tid så meget energi, at den tager sig sammen til at slå ham ihjel. Den moderne martyrs opgave er følgelig at vække tilstrækkelig intens vrede og forbitrelse; han må vække lidenskaben i en lidenskabsløs tid. Denne vakte lidenskab skal i sit chokerende frembrud, og med sit ikke mindre chokerende resultat, blive en afgørende faktor, der kan gøre en forskel midt i al indifferensen. Kun således kan der, på det religiøses gebet, bringes afgørende nyt ind i verden på et tidspunkt, hvor enhver mulighed for en gennemgribende ændring af tingenes tilstand synes at være umuliggjort af nivelleringen. Kun en moderne martyr kan således gøre en forskel i modernitetens tidsalder, som i et og alt modsætter sig, at der gøres afgørende forskel på nogen eller noget.

Kierkegaard vaklede dog stærkt i troen på, at en moderne martyr kunne lykkes med sit forehavende. Som det for eksempel fremgår af den første af pseudonymet H. H.'s Tvende Ethisk-Religieuse Smaa-Afhandlinger, der eksplicit afskriver martyriet som en etisk set utilladelig mulighed, tvivlede Kierkegaard stærkt på, at det overhovedet ville være muligt at vække den fornødne lidenskabelige forbitrelse i en så gennemreflekteret tid som hans samtid. I stedet taler han, med sine egne erfaringer fra Corsar-striden i baghovedet, om, at det højest mulige for den, der søger martyriet i en sådan tid, er at blive en grinets martyr, en latterlig figur der udles for sin utidssvarende tåbelighed. H. H.’s tekst afsøger - og fremskriver! - dog stadigvæk, under dække af sin afstandtagen til martyriet, mulighedsbetingelserne for et moderne martyrium. ${ }^{17} \mathrm{Og}$ i Anmeldelsen kan man, som jeg her læser, ane et forstudie til denne fremskrivning.

Det er derfor ikke godt at vide, hvad hverdagshistoriens forfatter fik ud af teksten, ifald vedkommende læste den. Efter alt at dømme er Kierkegaards særegne form for indirekte meddelte og kontranivellerende marty-

17. Se i den forbindelse min artikel »H. H. - poet or martyr« i antologien Antropology and Authority, red. Houe, Marino og Rossel, Amsterdam og Atlanta 2000. 
rium ikke et tema, der spøger mellem linjerne i To Tidsaldre - hvad anmelderen retfærdigvis heller ikke påstår. Så meget desto tydeligere er det, at Thomasine Gyllembourgs historie for Kierkegaard er en anledning, en lejlighed til i det skjulte at reflektere over, hvilken radikal-kur samtiden behøver for at blive revet ud af refleksionens og nivelleringens garn, således at sand opbyggelse kan begynde at finde sted på baggrund af denne uhyre negativitet. Samtidig var der altså mulighed for på indtil flere forskellige måder at "pirre lidt ved Heiberg".

Man kan slutte, at Anmeldelsen på en og samme tid er en - i forhold til Af en endnu Levendes Papirer - gentagen anmeldelse af en helt anden kaliber, en forstudie til Kierkegaards senere analyser af martyriets mulighedsbetingelser i moderniteten, en uhyggeligt skarp og profetisk analyse af samme modernitet - og et produkt af et ganske dagligdags husligt spektakel i den altid fnidrede litterære andedam. 
